\title{
Ameloblastoma: unusual cause of chest wall mass and effusion
}

\author{
Rob J Hallifax, ${ }^{1}$ John Corcoran, ${ }^{1}$ Ketan A Shah, ${ }^{2}$ Najib M Rahman ${ }^{1}$
}

${ }^{1}$ Oxford Centre for Respiratory Medicine, Churchill Hospital, Oxford, UK

${ }^{2}$ Cellular Pathology, John Radcliffe Hospital, Oxford, UK

\section{Correspondence to} Dr Rob J Hallifax robhallifax@yahoo.com

\section{DESCRIPTION}

An 86-year-old man was referred with breathlessness and cough. A chest radiograph showed a large left-sided effusion and a chest wall mass. An urgent outpatient CT of the thorax confirmed the presence of the left-sided effusion but also showed new chest wall masses extending laterally (figure $1 \mathrm{~A}$ ), posteriorly and medially into thoracic vertebrae (figure 1B). Immediate radiotherapy (20 Gy in 5 fractions) was administered to treat the impending cord compression. Histological typing could have influenced the potential chemotherapy regime; therefore, realtime ultrasound-guided cutting-needle biopsy was performed.

Biopsy revealed metaplasia: cores of fibrous tissue containing anastomosing nests of epithelial cells, the peripheral cells of which showed palisaded nuclei and subnuclear vacuolations (figure $2 \mathrm{~A}$ ). The centre of the

A

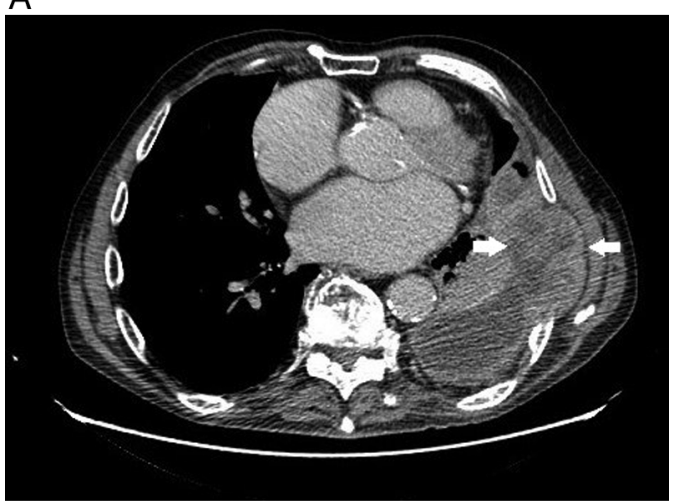

B

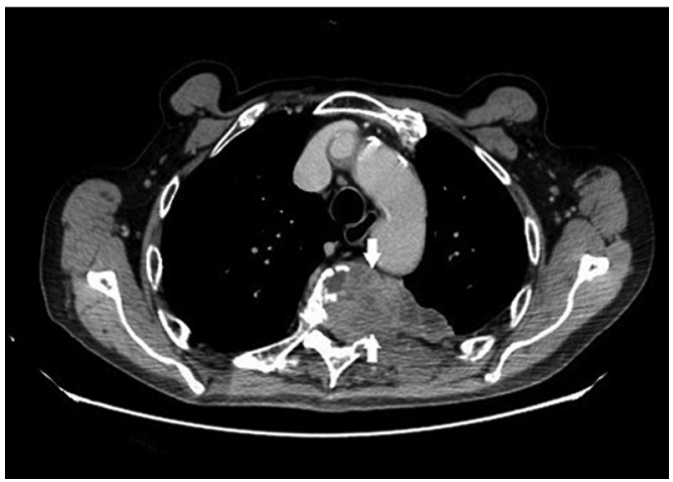

Figure 1 (A) An axial CT scan of the thorax showing a pleural mass invading the lateral chest wall with rib destruction ( $6 \mathrm{~cm}$ width indicated by arrows). (B) An axial CT scan of the thorax showing another mass invading the vertebrae and causing cord compression ( $5 \mathrm{~cm}$ width indicated by arrows). nests had the appearance of stellate reticulum with focal squamous metaplasia (figure 2B). These histological features were most in keeping with an ameloblastoma. Pleural fluid cytology was negative. Ameloblastoma is a rare tumour (although is the most common odontogenic tumour), ${ }^{1}$ usually regarded as a benign tumour which is locally aggressive $^{2}$ but does not necessarily confer a poor prognosis. $^{2}$

Metastases to lung and lymph nodes are relatively common, but not so for pleural or chest wall disease. ${ }^{3}$ On further questioning, it transpires that the patient had a jaw fracture (40 years ago) that required a pelvis graft. Unfortunately, the patient died from bronchopneumonia while an inpatient and so did not receive chemotherapy. This case appears to be a rare case of metastatic spread of an ameloblastoma to the chest wall.

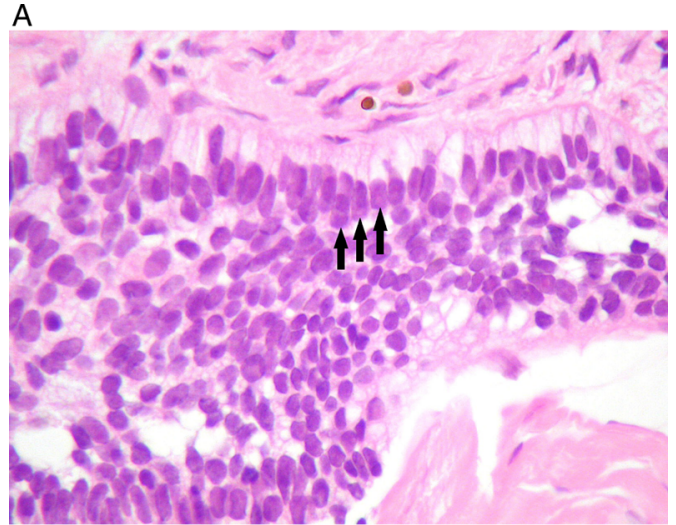

B

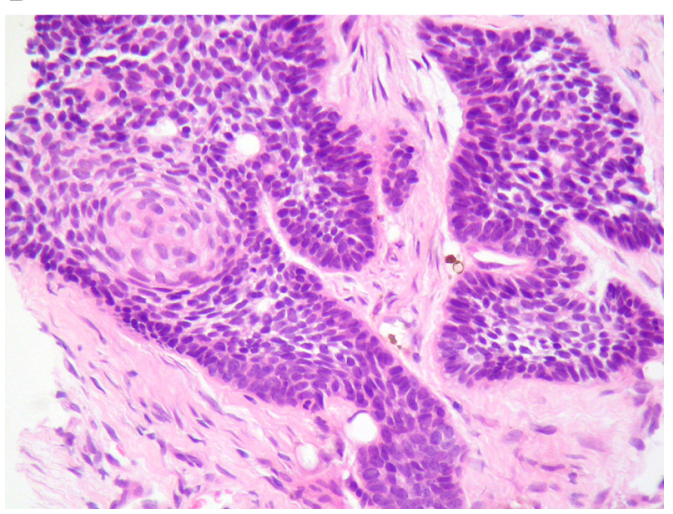

Figure 2 (A) Histology image: a high-power photomicrograph showing peripheral palisaded nuclei with reverse polarisation $(H \& E, \times 400)$. (B) Histology image: A medium-power photomicrograph showing central stellate reticulum with focal squamous metaplasia $(H \& E, \times 200)$. 


\section{Learning points}

- Ameloblastoma is a rare tumour of odontogenic tumour.

- Usually benign or causing local invasion only but can metastasise to lung, lymph nodes or pleura.

- Careful history and examination for potentially missed tumours of the jaw could elicit a rare primary source for undiagnosed chest wall masses.

Contributors All authors contributed to the management of this patient and composition of the article.
Competing interests None.

Patient consent Obtained.

Provenance and peer review Not commissioned; externally peer reviewed.

\section{REFERENCES}

1 Sciubba JJ, Fantasia JA, Kahn LB. eds. Benign odontogenic tumors. Atlas of tumor pathology: tumors and cysts of the jaw. Washington, DC: AFIP, 1999.

2 Kramer I, Pindborg J, Shear M. Histological typing of odontogenic tumors. Berlin: Springer, 1992.

3 Luo D, Feng C, Guo J. Pulmonary metastases from an ameloblastoma: case report. J Craniomaxillofac Surg 2012;40:470-4.

Copyright 2013 BMJ Publishing Group. All rights reserved. For permission to reuse any of this content visit http://group.bmj.com/group/rights-licensing/permissions.

BMJ Case Report Fellows may re-use this article for personal use and teaching without any further permission.

Become a Fellow of BMJ Case Reports today and you can:

- Submit as many cases as you like

- Enjoy fast sympathetic peer review and rapid publication of accepted articles

- Access all the published articles

- Re-use any of the published material for personal use and teaching without further permission

For information on Institutional Fellowships contact consortiasales@bmjgroup.com

Visit casereports.bmj.com for more articles like this and to become a Fellow 